\title{
Pengaruh Sinergi Foto Profil Media Jejaring Sosial dalam Meningkatkan Personal Branding
}

\author{
Elda Franzia \\ Program Studi Desain Komunikasi Visual, \\ Fakultas Seni Rupa dan Desain, \\ Universitas Trisakti \\ Jalan Kyai Tapa No. 1, Jakarta 11440 \\ Email: eldafranzia@gmail.com
}

\begin{abstract}
The development of information technology and social media nowadays has increased the importance level of online self-image. This research aims to acknowledge the variety of social media that has been used to improve personal branding and its effects to the respondent. The case study of this research is students and alumni of FSRD Trisakti University. This research uses a quantilative that is combination of the quantitative method and the qualitative method. A quantitative method contributed in defining the pattern of profile picture usage by the students and alumni of FSRD Trisakti University to form the personal branding. A qualitative method contributed in giving an explorative description of visual language in those social media profile pictures. The result of this research is that the personal branding of the respondents can be increased by (1) showing the respondents' passion using the photo object and activity, (2) having an understanding about respondents' self-image, (3) showing the image repeatedly and consistently, and (4) using various social media as their functions and objectives.
\end{abstract}

Keywords: synergy, social media, profile picture, personal branding

\begin{abstract}
ABSTRAK
Perkembangan teknologi informasi dan media jejaring sosial saat ini menyebabkan pentingnya pencitraan diri di media online. Penelitian ini bertujuan untuk mengetahui ragam media jejaring sosial yang digunakan untuk pembentukan personal branding dan pengaruh sinergi tersebut pada responden. Studi kasus pada penelitian ini adalah mahasiswa dan alumni FSRD Universitas Trisakti. Metode yang digunakan pada penelitian ini adalah metode kuantilatif, yang memadukan metode kuantitatif dan kualitatif. Metode kuantitatif untuk mendefinisikan pola penggunaan foto profil responden dalam upaya pembentukan personal branding, sedangkan metode kualitatif memberikan deskripsi eksploratif tentang bahasa visual yang digunakan pada foto profil media jejaring sosial tersebut. Hasil penelitian ini adalah untuk meningkatkan pembentukan personal branding responden dapat dilakukan dengan cara (1) menampilkan minat pada foto profil dengan menggunakan objek foto sesuai minat tersebut, (2) memiliki kesadaran akan citra diri individu, (3) menampilkan secara konsisten dan berulang, dan (4) menggunakan beragam media jejaring sosial sesuai dengan fungsi dan tujuannya.
\end{abstract}

Kata kunci: sinergi, jejaring sosial, foto profil, personal branding 


\section{PENDAHULUAN}

Sejalan dengan perkembangan teknologi informasi dan media jejaring sosial saat ini, pencitraan diri di media online semakin berperan penting dalam membentukidentitas diri seseorang dalam masyarakat sosial. Bagaimana seseorang tampil di ruang faktual dan membentuk representasi dirinya di media jejaring sosial, menjadi citra diri yang membentuk persona dan penilaian orang lain atas dirinya. Personal branding sebagai pencitraan diri merupakan cerminan jati diri seseorang yang sering kali dikaitkan dengan kualitas kemampuan dan kapabilitas profesional seseorang. Dalam arus perkembangan media komunikasi tersebut, pencitraan terjadi secara simultan, baik dalam ruang dan waktu nyata maupun dalam berbagai ruang representasi virtual.

Perkembangan media sosial di Indonesia semakin berkembang pesat sejak didukung oleh infrastruktur baik berupa perangkat, jaringan internet, maupun teknologi. Saat ini, terdapat berbagai jenis media jejaring sosial yang populer digunakan di Indonesia. Pada Februari 2015, berdasarkan pooling dari Asosiasi Penyelenggara Jasa Internet Indonesia (APJII), penggunaan situs jejaring sosial merupakan aktivitas digital paling populer di Indonesia mengalahkan aktivitas browsing dan pencarian informasi. Pengguna perempuan sebesar 51\% dan laki-laki sebesar $49 \%$. Usia $18-25$ tahun sebesar 49\%, usia 26-35 tahun sebesar $33.8 \%$, sehingga lebih dari $80 \%$ pengguna internet adalah di bawah 36 tahun dan aktif mengakses media jejaring sosial. Akses terbesar dilakukan melalui telepon selular yaitu sebesar 85\%. (http://www.emarketer. com/Article/Indonesia-Social-NetworkingTops-List-of-Digital-Activities/1012582).

Pengguna media jejaring sosial memiliki kebebasan dalam menentukan pilihan media jejaring sosial yang digunakan dan foto profil yang digunakan sebagai representasi dirinya. Berdasarkan survei yang dilakukan oleh JAKPAT Mobile Survey pada Januari 2016 kepada 1033 responden dari JAKPAT Panel, urutan sosial media yang populer digunakan adalah (1) Facebook, (2) Instagram, (3) Twitter, (4) Path, (5) Google Plus, (6) LinkedIn, (7) Snapchat, (8) lain-lain, dengan urutan aktivitas update status adalah pada Facebook 59.56\%, Path (22.88\%), Instagram (20.56\%), Twitter (16.22\%) (http://blog.jakpat.net/indonesia-social-media-trend-2016free-survey-report/).

Dari penelitian sebelumnya, diketahui bahwa kebutuhan akan pembentukan personal branding dirasakan oleh mahasiswa dan alumni FSRD Universitas Trisakti sebagai desainer muda Indonesia dalam pasar global saat ini di mana kesempatan dan persaingan industri kreatif menjadi semakin ketat. Salah satu media pembentukan personal branding adalah media jejaring sosial, Facebook, khususnya melalui identitas diri yang ditampilkan melalui nama akun, foto profil, dan foto cover pada akun pribadi (Franzia, 2015). Perkembangan media sosial tersebut pada akhirnya menutut setiap orang untuk meningkatkan cara-cara dan pendekatan guna membangun personal branding.

Kehadiran seseorang dalam media jejaring sosial menjadi penting untuk menyebarkan pesan kepada orang lain tentang siapa diri seseorang. Selain itu, untuk memelihara personal branding yang telah dibentuk, pemilik akun perlu secara konsisten menyajikan branding tersebut di berbagai media jejaring sosial dan juga dalam kehidupan realitas. Media jejaring sosial lain seperi Twitter, Instagram, YouTube, Path, dan sebagainya dapat mempergunakan foto profil yang sama ataupun berbeda, selama menyampaikan penempatan posisi yang sama bagi pemilik akun. Personal branding yang dibentuk secara sinergi dan berkelanjutan akan semakin memperkuat posisi personal dan profesional individu di masyarakat. 
Mahasiswa dan alumni FSRD Universitas Trisakti menjadi bagian dari perkembangan teknologi global saat ini, dan mempunyai kepentingan dalam pembentukan personal branding sebagai desainer muda Indonesia. Pembentukan personal branding dapat dilakukan melalui berbagai media jejaring sosial, khususnya melalui tampilan foto profil yang digunakan. Ragam bentuk dan gaya gambar yang digunakan menimbulkan penyampaian pesan yang berbedabeda terhadap citra diri dan personal branding individu tersebut. Untuk itu, penelitian ini bertujuan mengetahui dan memahami ragam media jejaring sosial yang digunakan untuk pembentukan personal branding, ragam foto dan gaya visual pada foto profil yang membentuk sinergi personal branding, dan pengaruh sinergi media jejaring sosial tersebut pada responden.

\section{METODE}

Metode yang digunakan pada penelitian ini adalah metode kuantilatif, yang memadukan antara metode kuantitatif dan kualitatif. Penelitian dilakukan dalam dua tahap, yaitu tahap kuantitatif kemudian kualitatif. Dalam ilmu Desain Komunikasi Visual dapat dilakukan penelitian gabungan, agar data dan hasil analisis kuantitatif digunakan untuk memfasilitasi penelitian kualitatif. Metode kuantitatif membantu mendefinisikan pola penggunaan foto profil oleh mahasiswa dan alumni FSRD Universitas Trisakti dalam upaya pembentukan personal branding yang mendukung profesinya, sedangkan metode kualitatif digunakan untuk memberikan deskripsi yang kuat dan eksploratif tentang bahasa visual yang digunakan pada foto profil media-media jejaring sosial tersebut. Variabel penelitian adalah (a) foto profil (independent variable), dan (b) personal branding (dependent variable).

Objek penelitian adalah foto profil pada beragam media jejaring sosial yang digu- nakan oleh mahasiswa dan alumni FSRD Universitas Trisakti yang dipilih berdasarkan kuantitas media jejaring sosial yang digunakan, keragaman dan konsistensi jenis foto profil, serta gaya visual yang digunakan dalam merepresentasikan karakter dan keahlian pemilik akun tersebut. Observasi dilakukan secara daring dan perekaman data visual menggunakan metode download dan screen capture.

Batasan media sosial yang dipilih adalah media jejaring sosial, media mikroblog, dan media berbagi image (foto dan video). Media jejaring sosial dipilih karena merupakan media sosial yang paling popular digunakan di Indonesia (http://www.emarketer.com), termasuk Facebook, LinkedIn, GooglePlus, Foursquare, Path, Snapchat, AskFm. Media mikroblog dipilih karena termasuk dalam aktivitas sosial media yang banyak digunakan di Indonesia, termasuk Twitter. Media berbagi (media sharing) foto dan video (image) dipilih karena berkaitan dengan keilmuan dan keahlian desain, termasuk Instagram, YouTube, Vimeo, Tumblr, DevianArt, 4shared. Data mendalam didapatkan melalui kuesioner dan wawancara kepada responden meliputi maksud dan tujuan pemilihan foto profil pada akun jejaring sosial, persepsi dari pemilik akun lain, serta tanggapan dan feedback yang diperoleh pemilik akun sebagai akibat dari visual yang digunakan pada akun media jejaring sosial tersebut

Analisis dilakukan dengan metode referensi kepustakaan, yaitu dilakukan berdasarkan teori pembentukan personal branding di media sosial dari MarkPlus Institute, yaitu PDB (Positioning, Differentiation, Branding). Data tentang aspek penempatan brand (Positioning), unsur pembeda (Differentiation), dan personal brand (branding) yang dibentuk oleh responden didapatkan melalui data mendalam dari kuisioner dan responden. Ketiga aspek tersebut direlasikan dengan visual foto profil yang digu- 
nakan oleh responden di berbagai media jejaring sosialnya.

\section{HASIL DAN PEMBAHASAN}

Konsep brand dalam dunia usaha didefinisikan sebagai persepsi dan emosi yang dimiliki oleh pembeli atau prospektif pembeli, dan dipaparkan melalui pengalaman pembeli dalam mengonsumsi atau berhubungan dengan produk dan jasa tersebut. Apabila konsep tersebut diaplikasikan dalam konteks personal, maka personal brand adalah persepsi dan emosi yang dimiliki oleh orang lain terhadap diri seseorang yang mendefinisikan secara menyeluruh pengalaman dalam relasi antarpersonal tersebut (McNally, 2009). Personal branding didasarkan atas nilai-nilai kehidupan dan memiliki relevansi tinggi terhadap siapa sesungguhnya diri seseorang. Personal branding menjadi merek atau brand pribadi seseorang, yang menempel di benak orang lain pada saat berpikir tentang diri orang tersebut, dan membuat seseorang unik dan berbeda dengan orang lain. Menurut McNally dan Speak, terdapat 3 (tiga) dimensi utama pembentuk personal branding, yaitu (a) kompetensi atau kemampuan individu, (b) gaya atau style personal, dan (c) standar personal seseorang.

Penyampaian sebuah personal brand harus secara konsisten dan terus-menerus. Visibility menjadi lebih penting daripada kemampuan (ability). Untuk menjadi visible, seseorang harus mempromosikan dirinya menggunakan setiap kesempatan untuk memasarkan dan memperoleh keuntungan bagi dirinya. Oleh karena itu, kehidupan pribadi seseorang di balik personal brand yang dibangun harus sejalan dengan etika moral dan sikap yang telah ditentukan oleh personal brand tersebut. Kehidupan pribadi menjadi cerminan dari citra yang ingin ditanamkan dan ditampilkan dalam personal brand. Dalam perjalanan kehidupan pribadi seseorang, personal brand membutuhkan waktu untuk tumbuh dan berkembang, sehingga dalam setiap tahapannya personal brand harus konsisten dan teguh dari awal pembentukannya. Sebuah personal brand yang baik akan memberikan hasil yang baik dan bertahan lebih lama, jika seseorang secara konsisten dan terus-menerus dipersepsikan oleh orang lain dengan cara yang positif. Sosok personal tersebut harus diasosiasikan dengan sebuah nilai atau ide yang diakui secara umum memiliki nilai positif dan bermanfaat.

Personal branding membutuhkan media dalam pengembangannya. Selain dikembangkan di lingkungan kerja dan pasar realitas, personal branding saat ini juga sangat penting untuk dibangun di ruang virtual. Internet telah memberikan banyak perubahan dan peluang bagi pengembangan karir masyarakat kontemporer. Berkembangnya sistem jejaring dan internet yang menghubungkan individu dengan individu lain di ruang virtual mengubah cara berpikir dan membentuk identitas individu. Diri kedua atau second self hadir pada saat individu online dan berada dalam ruang virtual, sedangkan diri realitas merupakan adalah diri pada saat offline (Ensslin dan Muse, 2011).

Perkembangan ini berupa keuntungan dan kemudahan yang difasilitasi oleh internet. Mulai dari kemudahan mencari informasi sampai dengan pengembangan usaha dengan modal dan biaya operasional yang minim. Salah satu media yang tepat dan efektif dalam membangun personal branding di lingkungan virtual adalah melalui media sosial dan situs-situs jejaring sosial.

Menurut Marisqa Debora dari MarkPlus Institute, langkah awal dalam membentuk personal branding di media sosial adalah menentukan PDB (Positioning, Differentiation, Branding). PDB merupakan satu kesatuan yang saling mendukung personal branding seseorang. Positioning, merupakan identitas yang jelas ingin ditanamkan 
dalam benak orang lain terhadap diri seseorang. Positioning menjadi jelas apabila diperkuat dengan diferensiasi yang unik dan kokoh dari seseorang. PDB akan menjadi identitas seseorang yang terbangun di benak orang lain dan menjadi cerminan citra diri profesional seseorang (www.themarketeers.com). Setelah PDB dibentuk secara personal, media yang digunakan adalah media sosial dan situs-situs jejaring sosial seperti Facebook, Twitter, Instagram, Google+, Pinterest, dan sebagainya.

Terdapat 6 (enam) kategori media sosial, yaitu (1) media jejaring sosial (social networking) termasuk Friendster, Facebook, LinkedIn, Foursquare, Path, MySpace; (2) jurnal daring (blog) termasuk Blogspot, WordPress, Multiply; (3) jurnal daring sederhana (microblogging) termasuk Twitter, Tumblr, Plurk; (4) media berbagi (media sharing) termasuk Instagram, Photobucket, DevianArt, YouTube, Vimeo, 4shared; (5) Penanda sosial (social bookmarking) termasuk Reddit, Amazon, GoodReads; dan (6) media konten bersama (wiki) termasuk Wikipedia, Wiki Ubuntu-ID (Nasrullah, 2015). Media jejaring sosial merupakan media yang paling populer dan paling banyak digunakan untuk berinteraksi satu sama lain. Interaksi tidak hanya pada pesan teks, tetapi juga termasuk foto dan video yang mungkin menarik perhatian pengguna lain. Semua posting (publikasi) merupakan real time, memungkinkan pengguna untuk berbagi informasi (Saxena dalam Nasrullah, 2015). Karakter utama dalam media jejaring sosial adalah setiap pengguna membentuk jaringan pertemanan, baik terhadap pengguna yang sudah dikenal dan sering bertemu di dunia nyata, maupun pengguna yang belum dikenal sebelumnya di dunia nyata.

Seseorang dapat memokuskan diri pada penggunaan salah satu jejaring sosial ataupun menggunakan berbagai jejaring sosial secara menyeluruh, dengan mempertimbangkan kemampuan personal. Identitas

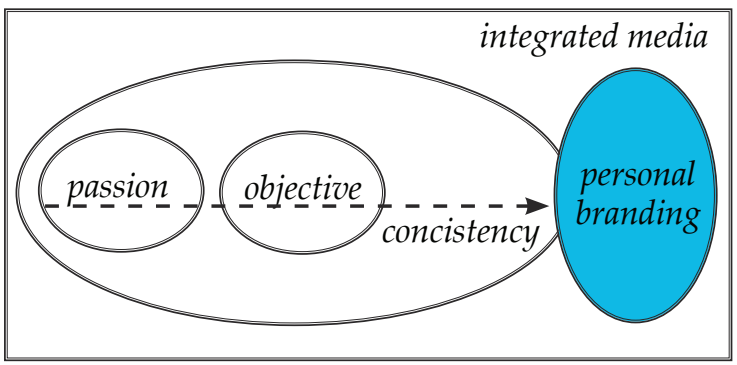

Gambar 1. Model POCI

(Sumber: http://efastbook.blogspot.com/2011/06)

juga diperkuat melalui blog pribadi yang unik, simpel, fokus, konsisten, dan terintegrasi dengan jejaring sosial yang digunakan. Pemilihan jejaring sosial dapat melalui rekomendasi lingkungan dan menggunakan mitra dalam pengelolaan. Hal ini akan memberikan keuntungan dan kemudahan dalam membangun identitas.

Dalam model POCI (Passion - Objective - Consistency - Integrated Media) pada gambar 1 , peran media yang terintegrasi dalam membangun personal branding adalah sangat penting. Media yang terintegrasi akan membuat persebaran personal branding yang telah dibuat menjadi semakin luas, karena fungsi dan sifat media jejaring sosial masing-masing berbeda.

Sifat dan fungsi media virtual tersebut antara lain, sebagai berikut. (a) Blog, merupakan media informasi yang dapat memuat opini dan dapat dicantumkan nama, foto, profil diri, dan nomor kontak, serta jejaring sosial lain yang terintegrasi; (b) Twitter, memiliki fungsi untuk berkomunikasi dengan singkat namun konsisten, dan menjaring orang-orang dengan minat dan keingintahuan sesuai bidang profesi. Komunikasi dapat dilakukan dengan memberikan info-info singkat, dan mention dengan akun Twitter terkait; (c) Facebook, memiliki fungsi integrasi dengan Twitter, dapat menampung posting gambar secara lebih leluasa, dan mempermudah pencarian orang lain terhadap diri seseorang; (d) Grup dan Forum, merupakan media diskusi dan membahas berbagai topik pada 


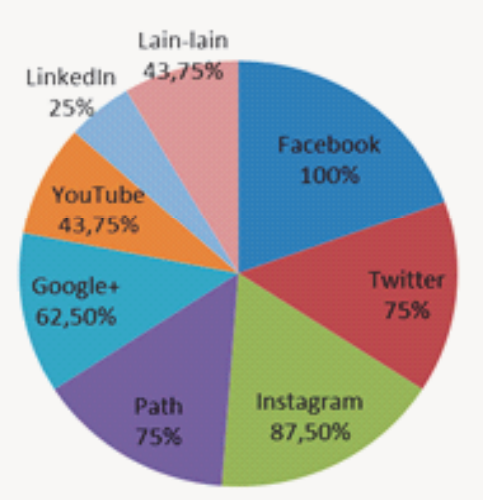

Gambar 2. Jejaring sosial yang digunakan oleh responden (Sumber: Franzia, 2017) bidang tertentu sehingga semakin banyak keterlibatan seseorang dalam diskusi akan menjadikan sosok dominan dan terpercaya oleh anggota forum yang lain; (e) Thread, menciptakan topik yang menarik akan dibaca dan ditanggapi banyak orang, sehingga sosok seseorang dapat semakin dikenal. Pada thread dapat dicantumkan linkblog dan signature sehingga semua pembaca dapat mengenal sosok tersebut; dan (f) Mensinergikan dengan aktivitas offline, antara lain dengan cara menjadi pembicara seminar ataupun publikasi dan kerjasama dengan kegiatan-kegiatan lain yang sesuai dengan kompetensi bidang keahlian (http://efastbook.blogspot.com/2011/06).

\section{Analisis Kuantitatif Aktivitas Responden dalam Penggunaan Jejaring Sosial}

Pengamatan yang dilakukan terhadap 25 akun jejaring sosial mahasiswa dan alumni FSRD Universitas Trisakti. Media jejaring sosial yang digunakan oleh responden meliputi media jejaring sosial, media mikroblog, dan media berbagi image (foto dan video). Berdasarkan penggunaan media jejaring sosial, $100 \%$ responden merupakan pengguna Facebook, 75\% pengguna Twitter, $87.5 \%$ pengguna Instagram, $75 \%$ pengguna Path, $62.5 \%$ pengguna Google+, $43.75 \%$ pengguna YouTube, $25 \%$ pengguna LinkedIn, $43.75 \%$ pengguna jejaring sosial lain seperti Snapchat dan Line.

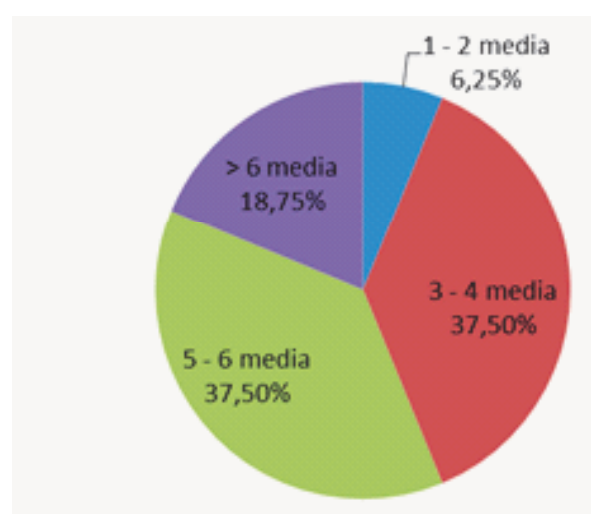

Gambar 3. Jumlah jejaring sosial yang digunakan oleh responden (Sumber: Franzia, 2017)

Gambar 3 menunjukkan bahwa berdasarkan kuesioner yang diberikan, pada umumnya responden menggunakan lebih dari satu media jejaring sosial. Hanya ada $6.25 \%$ responden yang menggunakan dua media jejaring sosial, $37.5 \%$ responden menggunakan tiga sampai empat media jejaring sosial, $37.5 \%$ responden menggunakan lima sampai enam media jejaring sosial, dan ada $18.75 \%$ responden menggunakan lebih dari enam media jejaring sosial.

Dalam hal tujuan penggunaan media jejaring sosial, responden memanfaatkan media jejaring sosial untuk beragam keperluan, yaitu (a) Sosial, termasuk tujuan komunikasi, mengirimkan pesan, posting status, foto, dan berita; (b) Rekreasional, termasuk untuk iseng dan hiburan; (c) Bisnis, termasuk untuk promosi produk dan jasa, serta membangun relasi; (d) Lain-lain. Tujuan rekreasional banyak dipilih karena responden banyak menggunakan media jejaring sosial pada waktu senggang, dan lebih jarang mengakses jejaring sosial pada saat sibuk.

Penggunaan media jejaring sosial tujuannya adalah untuk keperluan bisnis. Tujuan bisnis tidak menjadi tujuan utama penggunaan jejaring sosial, dan seringkali menjadi fungsi sampingan dari responden. Oleh karena terpenuhi tujuan sosialnya, maka responden sekaligus menawarkan 


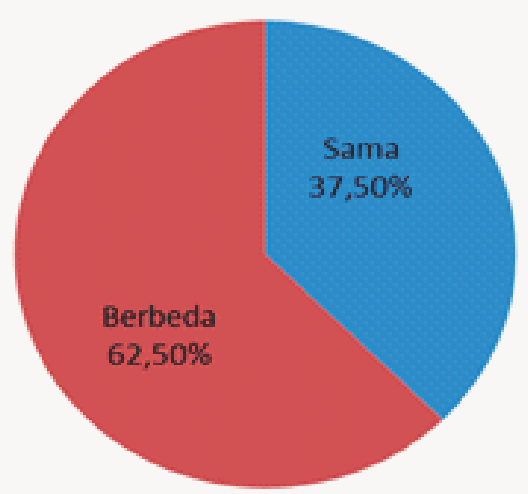

Gambar 4. Penggunaan foto profil responden di berbagai media jejaring sosial

(Sumber: Franzia, 2017)

barang, jasa, usaha yang dikerjakan kepada teman-teman di jejaring sosialnya. Fungsi bisnis dari media jejaring sosial yang digunakan oleh responden lebih pada fungsi membangun jejaring dan membina hubungan dengan relasi. Tujuan lain yang diungkapkan oleh responden adalah untuk penyaluran hobi.

Foto profil yang digunakan oleh responden di berbagai media jejaring sosial tersebut cenderung berbeda-beda sesuai dengan pilihan dan kebutuhan responden. Gambar 4 menunjukkan bahwa terdapat sebanyak $62.5 \%$ responden menggunakan foto profil yang berbeda-beda, dan hanya $37 . \%$ responden yang menggunakan foto profil yang sama untuk berbagai media jejaring sosial yang dimilikinya.

Jenis foto profil yang digunakan terdiri atas foto diri, foto diri bersama orang lain, dan image atau gambar lain. Sebanyak 75\% responden menggunakan foto diri sebagai foto profil, $18.75 \%$ responden menggunakan image atau gambar lain, dan sebanyak $6.25 \%$ responden menggunakan foto diri bersama orang lain. Image atau gambar lain yang digunakan termasuk logo sebagai identitas diri, gambar tokoh anime, dan gambar karikatur.

Foto profil yang digunakan dirasakan sudah mencerminkan citra dirinya oleh $81 \%$ responden. Alasan yang dikemukakan adalah karena foto profil sudah menampil- kan foto dirinya, menampilkan hobi dan keahlian yang dimiliki, dan juga pada foto profil yang menampilkan logo identitas personal telah sesuai dengan citra diri yang ingin ditampilkan oleh responden. Hanya sebanyak $19 \%$ responden yang merasa bahwa foto profil yang ditampilkan belum mencerminkan citra dirinya. Hal ini disebabkan karena foto profil dianggap hanya menampilkan hal-hal tertentu dan masih banyak aspek lain tentang citra diri yang tidak dapat ditampilkan melalui foto profil tersebut, seperti ideologi, falsafah hidup, dan keahlian lain dari responden.

Meskipun demikian, secara umum responden menyatakan bahwa foto profil yang digunakan belum memberikan informasi tentang keahlian dan profesi. Hal ini diakui oleh $62.5 \%$ responden. Hanya $37.5 \%$ responden yang mengaku telah menggunakan foto profil yang memberikan informasi tentang keahlian dan profesinya. Foto profil yang digunakan memberikan peluang kerja dan mendatangkan klien diakui oleh $43 \%$ responden. Sebanyak $56 \%$ responden tidak merasakan manfaat penggunaan foto profil untuk memberikan peluang kerja.

\section{Analisis Kualitatif Foto Profil Responden di Berbagai Jejaring Sosial}

Terdapat beberapa aspek dalam fotografi, yaitu bahasa rupa dan komposisi, cahaya, subjek atau objek, dan keterkaitan dengan teknik pembuatan (Datoem, 2013).

Foto profil terdiri atas elemen-elemen visual, yaitu (a) objek foto profil, dan (b)

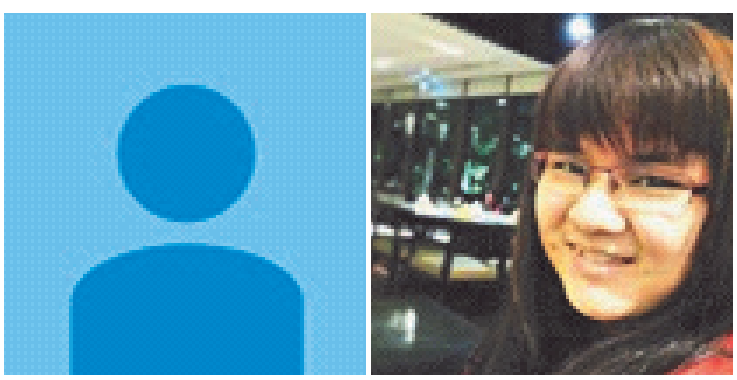

Gambar 5. Image dan foto diri pada foto profil (Sumber: Dokumentasi pribadi, Facebook, 2014) 
latar. Objek foto profil merupakan sosok utama yang terdapat di dalam foto dan menjadi pusat perhatian dari foto profil tersebut, sedangkan latar memberikan suasana dan menambahkan kesan pada foto profil. Pada foto, latar dapat berupa bentuk gambar jelas atau gambar yang dikaburkan (blur) yang didapatkan dari teknik fotografi tertentu. Latar dapat pula berupa bidang warna yang bersifat menonjolkan objek utama.

Berdasarkan ragam objek foto profil, terdapat 2 (dua) kategori umum, yaitu (a) foto diri, dan (b) image/gambar lain. Foto diri merupakan foto pemilik akun yang menjadi representasi tampilan diri pemilik akun, sedangkan image atau gambar lain adalah gambar-gambar yang digunakan oleh pemilik akun sebagai representasi citra dirinya.

Pada foto profil yang menampilkan foto diri, terdapat elemen-elemen lain yang mempengaruhi, yaitu (a) ekspresi, (b) gestur, (c) pakaian, dan (d) latar. Masingmasing elemen tersebut menyampaikan pesan tertentu bagi orang yang melihatnya. Ekspresi wajah menampilkan perasaan senang, sedih, ataupun ekspresi datar. Gestur atau bentuk gerak tubuh menampilkan kegiatan tertentu, atau relasi tubuh dengan sosok lain dan lingkungan. Gestur dapat menampilkan rasa kedekatan, nyaman, semangat, percaya diri, bangga, dan sebagainya. Gestur tidak mengomunikasikan pesan secara langsung, tetapi dapat dipahami dengan pengamatan terhadap objek dan lingkungannya. Pakaian menyampaikan suasana, kegiatan, dan gaya hidup pemilik akun. Latar menampilkan lingkungan, suasana, dan momen tertentu.

Foto diri dapat berupa foto wajah atau foto seluruh tubuh, dalam berbagai ekspresi dan suasana. Pose dan ekspresi merupakan bagian penting dari foto diri (Iskandar dkk., 2014). Salah satu keuntungan fotografi adalah individu dapat memblokir re- alitas tertentu sehingga menghasilkan citra visual yang sesuai dengan keinginan ( $\mathrm{Su}-$ trisna \& Sabana, 2015). Foto dapat menunjukkan secara jelas wajah ataupun kegiatan dan lingkungan di mana responden berada. Responden yang menggunakan foto diri pada foto profil menerapkan prinsip pembeda (Differentiation) melalui visual wajah yang menandakan identitas diri dan pembeda dari pemilik akun lain.

Pada akun media jejaring sosial, foto profil yang menampilkan foto diri paling banyak dipilih dan digunakan oleh pemilik akun. Hal ini disebabkan karena foto profil menjadi representasi diri dari pemilik akun dalam media jejaring sosial tersebut. Meskipun demikian, foto diri pada foto profil dapat menampilkan dengan jelas wajah pemilik akun tetapi juga dapat tidak secara jelas menampilkan wajah. Hal ini dipengaruhi oleh keinginan pemilik akun dan kesan yang ingin ditampilkan oleh pemilik akun pada akun media jejaring sosialnya.

Pada foto profil yang menampilkan $i-$ mage/gambar lain pada akun jejaring sosial, pemilik akun menjadikan gambar atau benda-benda tersebut sebagai representasi diri. Gambar tersebut memiliki relasi dengan diri, yang sering kali hanya dipahami oleh pemilik akun tersebut. Gambar tersebut dipilih karena dianggap sebagai identitas diri, atau dengan kata lain mencerminkan citra diri pemilik akun. Responden yang menggunakan foto profil berupa image tertentu pada umumnya menampilkan karya personal, antara lain logo, ilustrasi, karakter animasi, dan sebagainya.

Secara keseluruhan, objek foto, jarak pandang, dan latar membentuk gaya visual dan bahasa visual yang digunakan, yaitu pesan yang ingin disampaikan kepada pelihat. Pesan yang ingin disampaikan oleh responden melalui foto profil yang menggunakan objek foto diri dapat berbedabeda. Hal ini dipengaruhi oleh fokus foto tersebut sesuai dengan jarak padang dan 
warna. Pada foto diri dengan jarak pandang close-up dengan warna natural, maka identitas diri yang sebenarnya secara jelas terlihat. Pelihat akan menangkap dengan jelas citra diri responden sesuai dengan apa yang terlihat. Foto berwarna memberi nuansa realitas objek yang mendekati visual indera mata manusia (Sutrisna \& Sabana, 2015).

Berbeda dengan foto profil yang menampilkan objek foto diri dengan warna hitam putih. Pada foto dengan warna hitam putih, citra diri sebenarnya individu akan tersamarkan. Warna hitam putih tidak dapat menangkap warna kulit dan warna rambut sebenarnya, sehingga citra artistik lebih mengemuka.

Berdasarkan jarak pandang gambar, terdapat ragam jarak pandang foto profil, yaitu (a) extreme close-up, yang merekam bagian dari objek foto, atau bagian dari wajah, (b) close-up, yang merekam secara penuh objek foto atau wajah, (c) medium shot, yang merekam wajah sampai sebagian dari torso, (d) long shot, yang merekam keseluruhan tubuh dan sebagian dari lingkungan sekitarnya, dan (e) extreme long shot, yang merekam suasana lingkungan dengan objek terlihat kecil (Berger, 2007). Masing-masing ragam jarak pandang memiliki fungsi dan pesan komunikasi yang berbeda-beda. Pada foto profil dengan jarak pandang medium shot atau long shot, responden yang tidak mementingkan identitas dirinya terlihat dengan jelas. Hal ini dipengaruhi oleh fungsi jejaring sosial bagi responden yang digunakan untuk kebutuhan sosial kepada orang-orang yang dianggap telah mengenal dirinya di lingkungan sebenarnya. Responden ingin menampilkan situasi atau aktivitas di mana ia ingin diingat dan dikenali. Aktivitas tersebut dapat sesuai dengan profesi responden, juga dapat menampilkan aktivitas lain yang menimbulkan perasaan menyenangkan dan membanggakan bagi responden.
Gaya visual dan warna foto memengaruhi kesan secara keseluruhan dan apa yang diinginkan sebagai fokus pada foto tersebut. Pada medium shot dan long shot, gestur individu menjadi tampak jelas. Gestur adalah gerakan tubuh untuk mengomunikasikan sesuatu secara sadar maupun tidak sadar. Gestur dapat menjadi perilaku khas sebagai identitas diri (Gunarti, Piliang, \& Syarief 2013). Semakin jauh jarak pandang foto, semakin tidak jelas citra diri individu sebenarnya terlihat. Fokus pada foto akan lebih teralih pada benda-benda di sekitar individu.

Pada foto profil dengan objek foto berupa image atau gambar tertentu, masingmasing menyampaikan pesan tambahan selain identitas individu. Pada foto profil ini responden tidak merasa perlu untuk menunjukkan wajahnya, tetapi memilih menunjukkan asosiasi lain dari identitas dirinya. Responden yang menggunakan gambar untuk foto profil dapat memanfaatkan gambar tersebut untuk menampilkan gambar hasil karyanya, sehingga yang ingin disampaikan kepada teman di jejaring sosial adalah kemampuan atau keahlian yang ditunjang oleh gambar tersebut. Gambar dan keahlian terutama ditampilkan oleh responden dari Desain Komunikasi Visual, karena berkaitan dengan image seperti logo, animasi, dan komik. Responden dari Desain Interior dapat menampilkan lampu sebagai sub keahlian yaitu lighting atau pencahayaan.

Foto profil yang digunakan pada berbagai media jejaring sosial responden dapat sama ataupun tidak. Foto profil yang sama pada banyak jejaring sosial menunjukkan sinergi yang kuat antar media tersebut. Personal branding ditampilkan dengan jelas, karena semua media jejaring sosial tersebut menyampaikan pesan yang sama. Kesamaan pada foto profil yang digunakan oleh responden pada seluruh media jejaring sosialnya merupakan bentuk sinergi personal 
Tabel 1. Penggunaan foto profil sama pada seluruh jejaring sosial responden

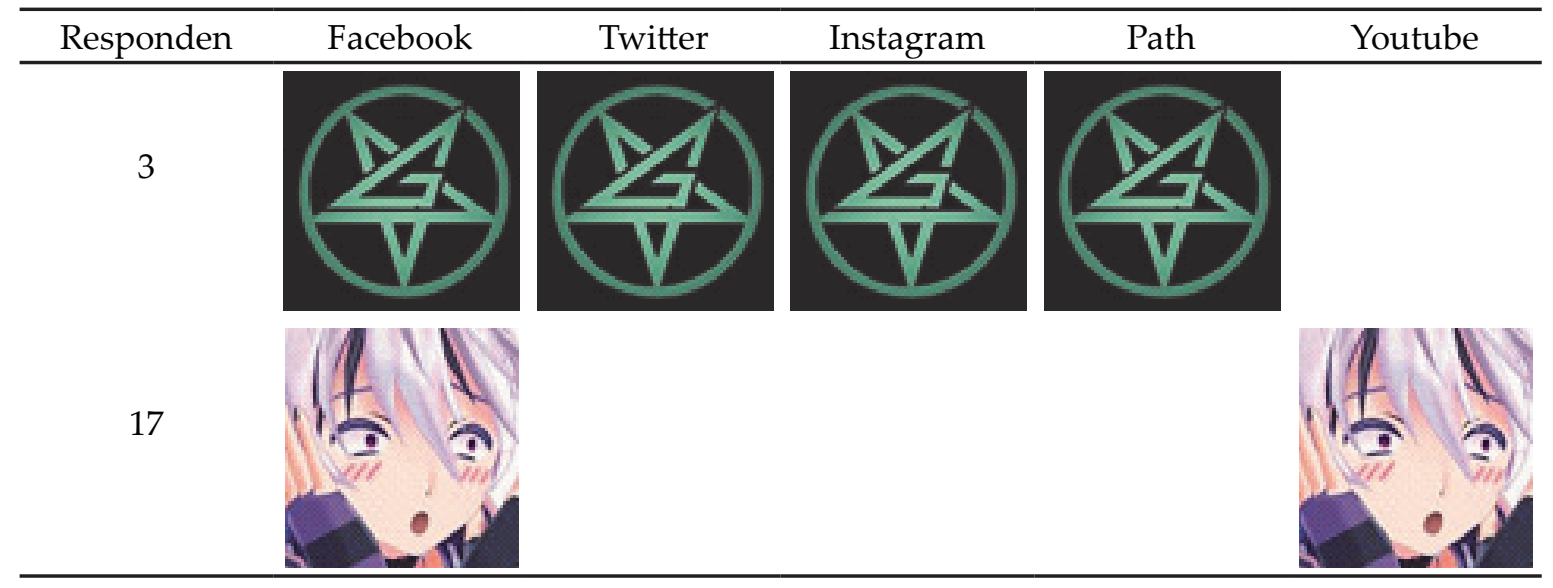

Sumber: Dokumentasi pribadi, Facebook, 2014

branding yang dibentuk oleh responden. Personal branding yang dibentuk berkaitan dengan keahlian sudah kuat.

Pada tabel 1, responden 3 (tiga) memiliki keahlian pada bidang khusus tipografi, perancangan logo dan branding. Responden membuat logo personal yang merepresentasikan diri. Citra diri responden divisualkan melalui self logo yang dibuat. Responden 17 menggunakan gambar wajah tokoh anime Jepang. Tokoh tersebut dipilih dengan alasan responden menyukai tokoh tersebut dan berhubungan dengan minat, keahlian, dan pekerjaan yang ditekuni.

Kesamaan pada foto profil yang digunakan oleh responden pada seluruh media jejaring sosialnya merupakan bentuk sinergi personal branding yang dibentuk oleh responden. Responden 3 dan responden 17 adalah alumni dari Program Studi Desain Komunikasi Visual. Personal branding yang dibentuk berkaitan dengan keahlian sudah kuat.

Responden 3 memiliki keahlian pada bidang khusus tipografi, perancangan logo dan branding. Hal ini tercermin dari foto profil yang digunakan. Responden membuat logo personal yang merepresentasikan diri. Citra diri responden divisualkan melalui self-logo yang dibuat. Responden mendefinisikan dirinya sebagai pribadi yang simpel, sporty, rockstyle. Selain itu responden memiliki minat pada band, clothing line. Keseluruhan citra diri tersebut pada akhirnya direpresentasikan melalui logo berbentuk lingkaran dan bintang tersebut. Bintang menjadi bentuk yang menarik bagi responden untuk diolah. Bintang juga dapat dipahami sebagai cita-cita dan tujuan. Sehingga secara keseluruhan logo tersebut menjadi cerminan kuat dari personal branding responden yang telah dipahami dan dimanfaatkan oleh responden sebagai foto profil akun pribadi di seluruh jejaring sosial miliknya.

Responden 17 menggunakan gambar wajah tokoh anime Jepang. Tokoh tersebut dipilih dengan alasan responden menyukai tokoh tersebut dan berhubungan dengan minat, keahlian, dan pekerjaan yang ditekuni. Responden merupakan alumni Program Studi Desain Komunikasi Visual yang memiliki keahlian animasi 2D. Akun yang paling aktif adalah YouTube, di mana responden menampilkan karya-karya animasinya. Responden memanfaatkan media jejaring sosial tidak secara langsung untuk pembentukan personal branding, tetapi dengan aktivitas responden dan relasi sosial responden dengan komunitas di jejaring sosial, maka responden memiliki peluang menampilkan keahlian dan citra diri terbentuk dari situ. Citra diri responden yang didefinisikan bersifat santai, humoris, jujur, keras kepala, introvert, didukung dengan 
Tabel 2. Penggunaan foto profil sama pada seluruh jejaring sosial responden

\begin{tabular}{|c|c|c|c|c|}
\hline Responden & $\begin{array}{l}\text { Sinergi Foto } \\
\text { Profil }\end{array}$ & $\begin{array}{l}\text { Citra Diri } \\
\text { yang Tampak }\end{array}$ & $\begin{array}{l}\text { Citra Diri Menurut } \\
\text { Responden }\end{array}$ & $\begin{array}{l}\text { Personal branding Menurut Res- } \\
\text { ponden dan yang Ditampilkan }\end{array}$ \\
\hline 3 & & $\begin{array}{l}\text { Graphic de- } \\
\text { signer } \\
\text { Minat pada } \\
\text { tipografi } \\
\text { Rock style }\end{array}$ & $\begin{array}{l}\text { Simpel } \\
\text { Sporty } \\
\text { Rock style }\end{array}$ & $\begin{array}{l}\text { Visual branding dan Typography } \\
\text { enthusiast } \\
\text { Self logo yang ditampilkan } \\
\text { mengomunikasikan keahlian } \\
\text { profesi dan minat dalam bidan } \\
\text { keahlian dan musik yang mem- } \\
\text { pengaruhi gaya individu. }\end{array}$ \\
\hline 17 & & $\begin{array}{l}\text { Minat pada } \\
\text { animasi Je- } \\
\text { pang } \\
\text { Introvert }\end{array}$ & $\begin{array}{l}\text { Santai } \\
\text { Humoris } \\
\text { Jujur } \\
\text { Keras kepala } \\
\text { Introvert }\end{array}$ & $\begin{array}{l}\text { Santai, humoris, apa adanya } \\
\text { Menampilkan bidang keahlian } \\
\text { dan sifat introvert dengan tidak } \\
\text { menampilkan wajah individu } \\
\text { sebagai identitas secara jelas. }\end{array}$ \\
\hline
\end{tabular}

Sumber: Dokumentasi pribadi, Facebook, 2014

minat dan keahlian responden pada bidang animasi yang membutuhkan ketekunan dalam pekerjaan personalnya, membentuk personal branding yang utuh.

Responden 3 dan responden 17 telah memiliki penempatan diri (Positioning) berdasarkan keahliannya, dan melakukan proses pembeda (Differentiation) secara konsisten dengan menggunakan logo pribadi atau wajah tokoh anime sebagai foto profil jejaring sosialnya. Beberapa responden lain yang memiliki akun di berbagai media jejaring sosial juga seringkali menggunakan foto profil yang sama atau mirip dalam beberapa jejaring sosial, dan menggunakan foto profil yang berbeda pada 1 atau 2 jejaring sosialnya. Hal ini juga berkaitan dengan citra diri yang dimiliki responden dan personal branding yang terbentuk.

Foto profil yang banyak digunakan adalah foto diri. Wajah responden terlihat jelas, dengan latar beragam. Media jejaring sosial seperti Facebook banyak digunakan oleh responden untuk relasi sosial dengan orang lain, sehingga foto diri digunakan sebagai representasi diri responden. Pada bentuk sinergi foto profil seperti ini, personal branding tidak kuat terbentuk.

Citra diri yang disampaikan lebih pada identitas pribadi dan hubungan personal dengan orang lain. Jejaring sosial tidak dimanfaatkan untuk menyampaikan keahlian dan pembentukan personal branding.

Dari hasil observasi visual, responden yang menggunakan foto profil yang berbeda pada media-media jejaring sosial miliknya lebih banyak dibandingkan dengan responden yang menggunakan foto profil sama. Meskipun semakin banyak media jejaring sosial yang digunakan responden, makin besar kemungkinan foto profil yang digunakan ada yang berulang digunakan pada jejaring sosial yang berbeda.

Pada tabel 3 ditunjukkan bahwa foto profil yang digunakan berbeda-beda juga memiliki benang merah yang mengomunikasikan pesan tertentu. Benang merah tersebut disimpulkan dari kesamaan elemen visual, yaitu objek, latar, dan warna.

Benang merah elemen visual menjadi bentuk sinergi dari foto profil yang ditampilkan. Sinergi foto profil tersebut mengomunikasikan citra diri individu. Pada responden yang memiliki banyak akun di jejaring sosial, dapat terbentuk lebih dari satu bentuk sinergi.

Bentuk sinergi foto profil yang didukung oleh kesamaan foto profil yang lebih banyak menjadi bentuk sinergi foto profil yang utama, sedangkan benang merah vi- 
Tabel 3. Penggunaan foto profil sama pada seluruh jejaring sosial responden

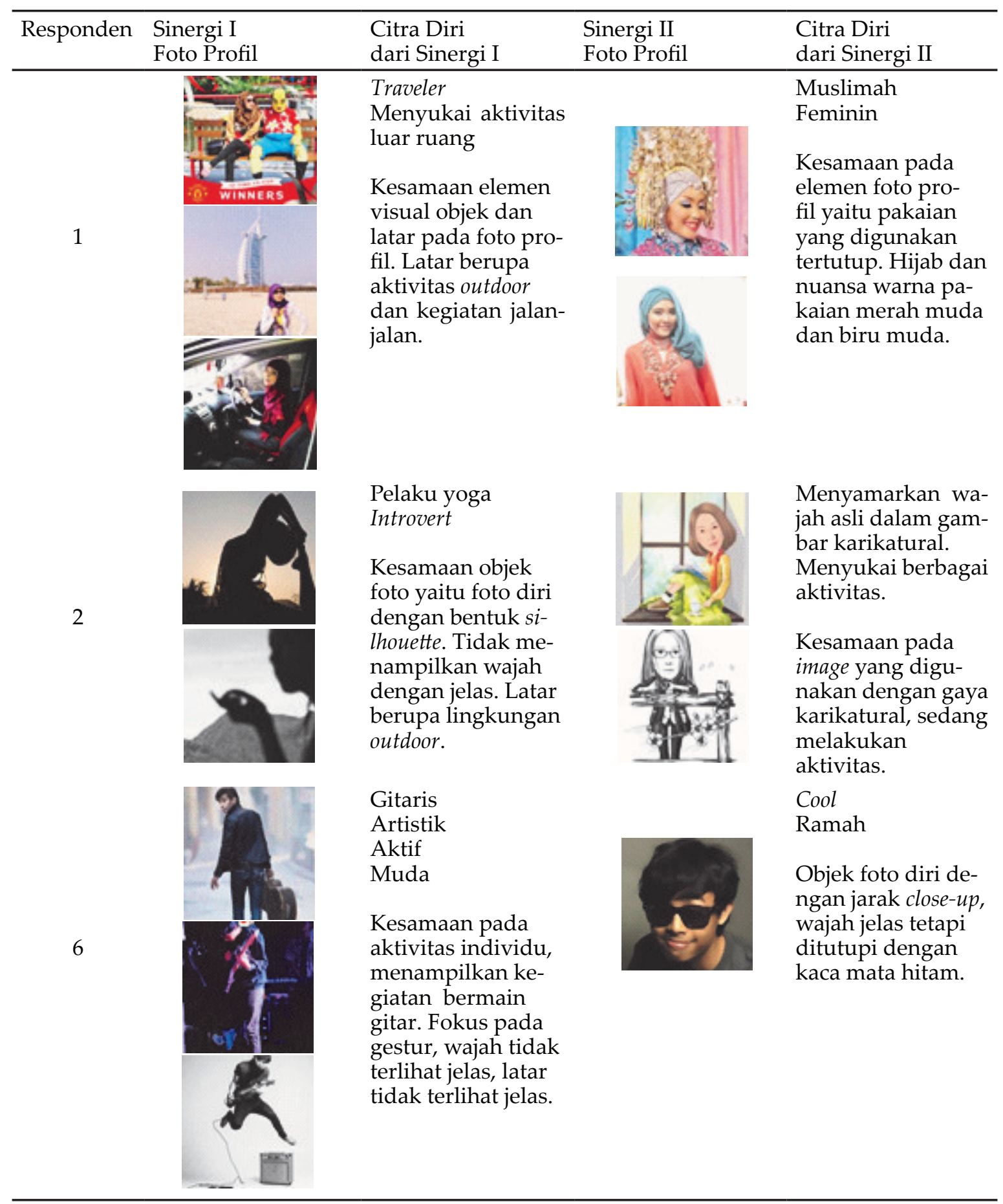

Sumber: Dokumentasi pribadi, Facebook, 2014

sual lain yang terbentuk menjadi bentuk sinergi foto profil pendukung.

Citra diri yang ditampilkan dari bentuk sinergi I dan bentuk sinergi II dapat bersifat mendukung, saling melengkapi, atau berbeda dan menjadi citra diri tambahan dari individu. Citra diri individu yang tampak dari sinergi foto profil memiliki kemungkinan sesuai atau tidak dengan pemahaman citra diri responden yang disadari berdasarkan hasil kuesioner. Citra diri individu dari sinergi foto profil direlasikan dengan citra diri menurut responden dan personal branding menurut responden, me- 
Tabel 4. Contoh sinergi foto profil berbeda dan personal branding

\begin{tabular}{|c|c|c|c|c|}
\hline Responden & $\begin{array}{l}\text { Citra Diri } \\
\text { dari Sinergi I }\end{array}$ & $\begin{array}{l}\text { Citra Diri } \\
\text { dari Sinergi II }\end{array}$ & $\begin{array}{l}\text { Citra Diri } \\
\text { Menurut } \\
\text { Responden }\end{array}$ & $\begin{array}{l}\text { Personal branding Menurut Responden } \\
\text { dan yang Ditampilkan }\end{array}$ \\
\hline 1 & $\begin{array}{l}\text { Traveler } \\
\text { Menyukai } \\
\text { aktivitas luar } \\
\text { ruang }\end{array}$ & $\begin{array}{l}\text { Muslimah } \\
\text { Feminin }\end{array}$ & $\begin{array}{l}\text { Ingin tau } \\
\text { Supel } \\
\text { Kurang peka } \\
\text { Lamban } \\
\text { Rajin }\end{array}$ & $\begin{array}{l}\text { Simpel } \\
\text { Tidak menampilkan profesi. } \\
\text { Menampilkan diri muslimah yang } \\
\text { memiliki rasa ingin tau dan kesukaan } \\
\text { pada kegiatan rekreasional. }\end{array}$ \\
\hline 2 & $\begin{array}{l}\text { Pelaku yoga } \\
\text { Introvert }\end{array}$ & $\begin{array}{l}\text { Menyamar } \\
\text { kan wajah } \\
\text { asli dalam } \\
\text { gambar kari- } \\
\text { katural. } \\
\text { Menyukai } \\
\text { berbagai akti- } \\
\text { vitas. }\end{array}$ & $\begin{array}{l}\text { Wanita } \\
\text { Yoga } \\
\text { Friendly } \\
\text { Independen } \\
\text { Fotografer }\end{array}$ & $\begin{array}{l}\text { Friendly } \\
\text { Tidak menampilkan profesi. } \\
\text { Menampilkan sosok wanita yang } \\
\text { menyukai aktivitas yoga dan tidak } \\
\text { merasa perlu menampilkan wajah se- } \\
\text { benarnya. }\end{array}$ \\
\hline 6 & $\begin{array}{l}\text { Gitaris } \\
\text { Artistik } \\
\text { Aktif } \\
\text { Muda }\end{array}$ & $\begin{array}{l}\text { Cool } \\
\text { Ramah }\end{array}$ & $\begin{array}{l}\text { Mengejutkan } \\
\text { Heboh } \\
\text { Berisik } \\
\text { Yakin } \\
\text { Optimis }\end{array}$ & $\begin{array}{l}\text { Pemberi kejutan } \\
\text { Tidak menampilkan bidang keahlian } \\
\text { tetapi menampilkan minat pada seni } \\
\text { melalui aktivitas bermusik dan gaya } \\
\text { visual fotografi yang aristik. }\end{array}$ \\
\hline
\end{tabular}

Sumber: Dokumentasi pribadi, Facebook, 2014

ngomunikasikan personal branding yang ditampilkan melalui foto profil.

Personal branding tersebut terbentuk dari ciri tertentu yang ditampilkan oleh individu pada foto profilnya. Relasi sinergi foto profil dengan personal branding yang terbentuk tidak langsung menyampaikan profesi dan keahlian responden. Hal ini sesuai dengan personal branding yang disampaikan oleh responden memiliki kecenderungan pemaparan sifat dan karakteristik personal responden.

Pemahaman masing-masing responden untuk pemanfaatan media jejaring sosial untuk penguatan personal branding masih rendah. Jejaring sosial, seperti Facebook dan Path, lebih dimanfaatkan untuk kebutuhan sosial. Sementara media yang berfungsi sebagai image sharing, seperti Instagram dan YouTube, lebih dimanfaatkan sebagai media dokumentasi portofolio digital.

Dampak positif bagi pembentukan dan penguatan personal branding dirasakan oleh responden antara lain karena foto profil yang menampilkan citra diri yang baik dan sesuai dengan yang ingin disampaikan oleh responden. Karena foto profil tidak dapat menampilkan karya dan keahlian responden secara informatif, foto profil lebih berfungsi sebagai identitas. Karya responden lebih banyak ditampilkan melalui posting pada media jejaring sosial tersebut. Foto profil menjadi pendukung dan penguat citra diri dan personal branding yang ingin ditampilkan oleh responden dalam pemahaman bahwa personal branding tersebut mendukung status dan kepercayaan sosial terhadap diri responden.

Relasi antara minat dan keahlian responden yang tampak pada foto profil dengan citra diri yang ditampilkan dan dipaparkan oleh responden, juga dengan personal branding yang terbentuk dipaparkan melalui implementasi Model POCI pada gambar 6 . Foto profil yang menampilkan keahlian tertentu atau minat responden terhadap bidang tertentu dan citra diri akan mengarahkan pemahaman secara langsung kepada personal branding yang terbentuk apabila diaplikasikan secara konsisten oleh 


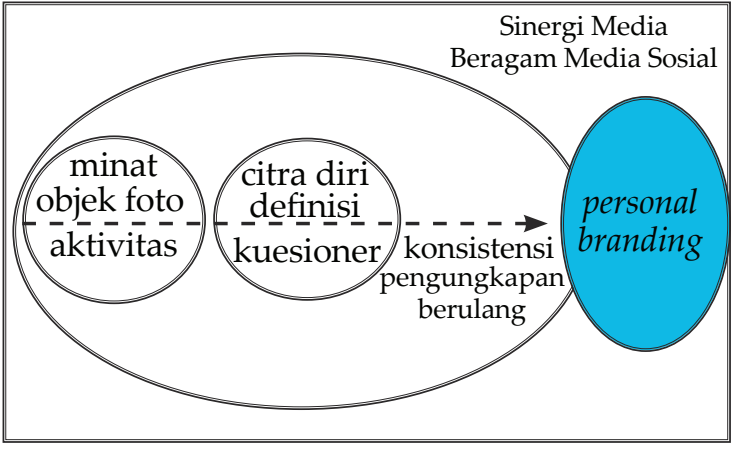

Gambar 6. Implementasi model POCI pada studi kasus penelitian

(Sumber: Franzia, 2014 adaptasi dari http:// efastbook.blogspot.com/2011/06)

responden pada berbagai media jejaring sosial. Kekuatan pembentukan dan penguatan personal branding dipengaruhi oleh tingkat konsistensi tersebut. Semakin banyak media jejaring sosial yang menyampaikan minat dan citra diri yang sama, maka semakin kuat personal branding yang terbentuk.

Demikian pula, apabila minat dan citra diri berbeda-beda, atau semakin sedikit media jejaring sosial yang menampilkan minat dan citra diri yang sama, maka semakin lemah personal branding yang terbentuk.

Dalam model POCI (Passion - Objective - Consistency - Integrated Media), peran media yang terintegrasi dalam membangun personal branding adalah sangat penting. Implementasi model tersebut dalam studi kasus terbatas ini, yaitu pada mahasiswa dan alumni Fakultas Seni Rupa dan Desain Universitas Trisakti adalah foto profil yang menunjukkan minat atau keahlian dan citra diri yang dibentuk dan tercermin dari foto profil dan hasil kuesioner secara konsisten pada berbagai media jejaring sosial akan memberi penguatan terhadap personal branding responden.

\section{SIMPULAN}

Beberapa jenis media jejaring sosial banyak digunakan oleh mahasiswa dan alumni FSRD Universitas Trisakti. Pada umumnya responden menggunakan 3 (tiga) sampai 6 (enam) jejaring sosial. Seluruh media jeja- ring sosial tersebut menggunakan foto profil sebagai representasi identitas individu. Individu dapat memilih foto profil apa yang ingin ditampilkan di jejaring sosial miliknya. Oleh karena itu, foto profil mencerminkan citra diri yang dimiliki dan diakui oleh individu.

Foto profil yang menampilkan karya individu seperti self-logo, logo usaha, karya ilustrasi, tokoh animasi, merupakan foto profil yang paling jelas mengomunikasikan profesi dan keahlian individu. Responden tersebut telah memiliki personal branding yang kuat dan kesadaran tinggi untuk memanfaatkan media jejaring sosial sebagai penguatan personal branding miliknya. Selain itu, foto profil yang menampilkan kegiatan dan aktivitas individu dapat mengomunikasikan perilaku dan aktivitas yang sering dilakukan oleh individu, sehingga objek foto demikian juga dapat berfungsi sebagai penguat personal branding.

Personal branding lebih kuat ditampilkan oleh responden yang menggunakan foto profil karya individu secara sinergi pada berbagai media jejaring sosial yang digunakannya. Setelah personal branding terbentuk, selanjutnya personal branding perlu dikomunikasikan melalui media-media tertentu, di antaranya media jejaring sosial. Semakin banyak media jejaring sosial yang dimanfaatkan untuk mengomunikasikan personal branding individu, maka pesan tentang personal branding akan semakin banyak diterima dan semakin dikenal oleh orang lain. Sebaliknya, apabila personal branding yang terbentuk tidak dikomunikasikan secara sinergis pada berbagai media, maka pesan tentang personal branding tersebut kurang diterima oleh orang lain.

Personal branding yang menyampaikan pesan kuat tentang keahlian dan profesi individu akan memberikan manfaat bagi individu secara profesional. Meskipun media jejaring sosial tidak secara utama memiliki fungsi bisnis, tetapi dalam situasi keluasan 
dan kecepatan teknologi informasi saat ini maka media jejaring sosial bersifat meluaskan jejaring dan mengomunikasikan secara real time ke sasaran yang sangat luas apa yang ingin dikomunikasikan oleh individu, baik citra diri maupun secara spesifik personal branding.

Oleh karena itu, maka untuk meningkatkan personal branding responden dapat dilakukan dengan cara: (1) menampilkan minat pada foto profil dengan menggunakan objek foto dan aktivitas sesuai minat tersebut; (2) memiliki kesadaran akan citra diri individu; (3) menampilkan secara konsisten dan berulang; dan (4) menggunakan beragam media jejaring sosial sesuai dengan fungsi dan tujuannya.

\section{Ucapan Terima Kasih}

Terima kasih kepada Dekan Fakultas Seni Rupa dan Desain Universitas Trisakti, Dewan Riset Fakultas Seni Rupa dan Desain dan Lembaga Penelitian Universitas Trisakti atas dukungan fasilitas dan dana sehingga terlaksananya penelitian ini. Terima kasih juga kami haturkan kepada para mahasiswa dan alumni Fakultas Seni Rupa dan Desain Universitas Trisakti yang menjadi responden pada penelitian ini.

\section{Daftar Pustaka}

Berger, A. A. (2007). Seeing is Believing. An Introduction to Visual Communication. Third Edition. New York: McGraw-Hill.

Datoem, A. (2013). Foto-Etnografi dalam Proses Penciptaan Karya Seni Fotografi. Panggung, 23 (2), 153-170.

Ensslin, A. dan Muse, E. (2011). Creating Second Lives, Community, Identity, and Spatiality as Construction of the Virtual. London: Routledge.
Franzia, E. (2015). Pengaruh Foto Profil dan Cover pada Jejaring Sosial Facebook dalam Membangun Personal Branding, Studi Kasus Mahasiswa dan Alumni FSRD Universitas Trisakti. Humaniora, 6 (3), 382-394.

Gunarti W.W.,W., Piliang, Y. A., Syarief, A. (2013). Wacana Visual Talks Show 'Mata Najwa': Melihat Bahasa Tubuh Partisipan sebagai Kekuatan Visual. Panggung, 23 (4), 369-385.

Iskandar, A., Sobarna, C., Mulyana, D., dan Risagarniwa, Y. Y. (2014). Kajian Budaya Fotografi Potrait dalam Wacana Personalitas. Panggung, 24 (3), 308-315.

McNally, D., dan Speak K. D. (2009). Be Your Own Brand, a Breakthrough Formula for Standing Out from the Crowd. San Fransisco, California: Berrett-Koehler Publishers.

Nasrullah, R. (2012). Komunikasi Antarbudaya, di Era Budaya Siber. Jakarta: Kencana Prenada Media Group.

Nn. (2015). In Indonesia, Social Networking Tops List of Digital Activities. Retrieved July 17, 2016, from http://www.emarketer.com/Article/IndonesiaSocial-Networking-Tops-List-of-Digital-Activities/1012582.

Nn. (2016). Indonesia Social Media Trend 2016, Free Survey Report Jajak Pendapat. Retrieved July 17, 2016, from http:// blog.jakpat.net/indonesia-socialmedia-trend-2016-free-survey-report/

Sutrisna, M., dan Sabana, S. (2015). Representasi Foto Keluarga: Ekspresi Seni Kontemporer pada Abad ke-21. Panggung, 25 (3), 279-291. 